\title{
W poszukiwaniu racjonalnej organizacji społeczeństwa. Tomasz More, Robert Owen a praktyka kibuców
}

\section{Wprowadzenie}

Celem artykułu jest przedstawienie i analiza wybranych rozwiązań organizacyjnych wspólnot opartych na tych samach zasadach, dzięki którym ich twórcy chcieli stworzyć idealny porządek społeczny. Podobne propozycje powstawały niezależnie od epoki, w której zostały stworzone (XVI wiek, XIX wiek, XX wiek). Racjonalność tych rozwiązań postaram się wykazać na przykładzie państwa Tomasza More'a ${ }^{1}$, New Harmony Roberta Owena ${ }^{2}$

1 Tomasz More (1478-1535) był angielskim prawnikiem, lordem kanclerzem za czasów Henryka VIII. Napisał Utopię. Ksiązeczkę zaiste złota i niemniej pożyteczna jak przyjemna o najlepszym ustroju państwa i nieznanej dotad wyspie Utopii (Lowanium 1516) w latach 1515-1516. Nie była to jedyna, ale na pewno pierwsza w tamtym okresie książka, która miała, jak pisał Witold Ostrowski, za „zadanie zachowanie jedności politycznej i religijnej Europy, pokoju międzynarodowego i reformy moralnej i społecznej" (T. More, Utopia, przeł. K. Abganowicz, wprow. W. Ostrowski, Warszawa 1954, s. 40). Wyrażała protest przeciwko rodzącemu się kapitalizmowi i rosnącej liczbie ubogich, a receptą na rozwiązanie tych problemów była opisana utopia społeczna. W 1535 roku został oskarżony o to, że nie uznał króla Henryka VIII za głowę Kościoła oraz sprzeciwiał się drugiemu małżeństwu króla. More'a skazano na śmierć. Król w drodze miłosierdzia zamienił mu okrutny sposób wykonania kary na ścięcie. Zob. szerzej S. Klonowicz, ,, Utopia” Tomasza Morusa, Kraków 1919, s. 10-13; T. More, op. cit., s. 9-26; A. Świętochowski, Utopie w rozwoju historycznym, Warszawa 1910, s. 31-37; K. Kautsky, Tomasz More i jego utopia, Warszawa 1949, s. 113-218.

${ }^{2}$ Robert Owen (1771-1858) był walijskim producentem tekstyliów, filantropijnym reformatorem społecznym i jednym z założycieli utopijnego socjalizmu i ruchu spółdzielczego. Właściciel zakładów włókienniczych New Lenark, w których wprowadził reformy dotyczące warunków i czasu pracy (między innymi skrócenie czasu pracy, podwyżka płacy, zakaz zatrudniania dzieci, ochrona pracy kobiet, ubezpieczenie robotników na wypadek choroby lub na starość); http://robert-owen-museum.org.uk/home (dostęp: 7.09.2018). 
oraz kibuców ${ }^{3}$ w Izraelu. Można między nimi zauważyć pewne prawidłowości polegające na tym, że powstanie fundamentalnych założeń tych wspólnot pokrywa się z momentami kryzysowymi w poszczególnych społeczeństwach, co doprowadzało do zmian w myśleniu ludzi o otaczającym ich świecie. Przedmiot badań stanowi organizacja tych wspólnot, która wyraża pragnienie uporządkowania świata. Występują bowiem zastanawiające paralele oraz intelektualne związki w ich zamysłach organizacyjnych, chociaż trudno znaleźć wpływ bezpośredni pomiędzy koncepcjami ich twórców ${ }^{4}$.

Państwo Utopia More'a to idea, natomiast Owen urzeczywistnił swoją ideę tworząc New Harmony. Są to idee dość reprezentatywne dla swoich epok i dlatego na nich się skupiam. Natomiast pierwsze kibuce (okresu drugiej-czwartej alii) powstały i funkcjonowały na zasadach tożsamych z obowiązującymi u T. More'a i R. Owena. Z tych także powodów artykuł mówi o wskazanych wspólnotach, które opierając się na podobnych zasadach i mając ten sam cel, jakim było

${ }^{3}$ Kibuc pochodzi od hebrajskiego słowa kvutzah (kwuca), które oznaczało grupę, wspólnotę; Leksykon politologii, red. A. Antoszewski, R. Herbut, Wrocław 2000, s. 199. Szerzej na temat kibuców zob. H. Near, The Kibbutz Movement: A History, Oxford 1992. Pochodzenie słowa thumaczy Aleksander Lewin, pisząc, że niektórzy uważają, że pochodzi Ono od słowa khila, co oznaczało „kanał, gmina, związek, korporacja, zgromadzenie, zbiór, gromada". Nie stwierdza jednak, że zgadza się z tą etymologią słowa „kibuc”. Odnosi się także do słowa $k$ wuca i podnosi, że kiedy powstawały pierwsze wspólnoty, to tak je nazywano, a dopiero później zaczęto je określać kibucami. „Wydaje się jednak, że jeśli chcemy dokładniej wyjaśnić, co to jest kibuc czy kwuca, nie możemy poprzestać na słowie grupa”. Lewin określił kibuc wspólnotą, której członkowie mają wspólne cele, wspólne dążenia i wspólną organizację —idem, Kibuce w Izraelu. Utopia czy rzeczywistość, Warszawa 1992, s. 10-11. Kibuce były zakładane przez Żydów pochodzących z Rosji i Europy Wschodniej. Uciekali oni przed prześladowaniami, które miały miejsce głównie w Rosji w XIX wieku, a także na początku XX wieku. Ucisk i gnębienie tych grup spowodowały masową emigrację do zachodniej Europy, Ameryki i Palestyny. Prawie 40\% Żydów z Rosji i Ukrainy do końca XIX wieku opuściło te kraje w poszukiwaniu bezpiecznego miejsca do życia. Pierwszym kibucem, który został założony przez grupę kilkunastu młodych uciekinierów z Białorusi w 1910 roku wzdłuż brzegów Galilei, była Degania. „Na pokładzie »Rusłana« płynącego z Odessy 19 grudnia 1919 roku przybyli do Palestyny ideologowie kibucu — to taki nasz izraelski »Mayflower«" mówił Alex Dancing (historyk, pracownik instytutu Yad Vashem), http://teatrnn.pl/leksykon/artykuly/alex-dancyg-ur-1948/ (dostęp: 19.12.2017). Zob. też A. Piątkowska, Kibuc - wcielona utopia, http://www.styl. pl/magazyn/news-kibuc-wcielona-utopia,nId,1463344 (dostęp: 20.04.2017). Od tamtej pory powstało w całym kraju około 300 kibuców (połowa z nich przed ustanowieniem państwa Izrael) i w pewnym stopniu wyznaczyło granice późniejszego Izraela. Większość kibuców została założona przez członków syjonistycznych ruchów młodzieżowych. Do powstania ruchu narodowego syjonizmu doszło pod koniec XIX wieku. Była to ideologia odrodzenia narodowego Żydów poprzez stworzenie w Palestynie własnej siedziby narodowej oraz odrodzenie języka hebrajskiego jako narodowego. Kibuce nadal istnieją w Izraelu, są różnorodne i oparte na zasadach, które w większości nie odpowiadają już pierwotnym regułom przyjętym przez pionierów.

${ }^{4}$ Celem artykułu nie jest wykazanie, że kibuce powstały na podstawie idei T. More'a czy R. Owena, gdyż tak nie było. Model organizacji kibucowej stworzył Franz Oppenheimer. Zaproponował on etnokomunalny model osadnictwa, który został przyjęty w środowiskach syjonistycznych. Zob. S. Sand, Kiedy i jak wynaleziono ziemię Izraela. Od Ziemi Świętej do ojczyzny, Warszawa 2015, s. 237-238. 
stworzenie lepszych warunków do życia, oprócz czasu, w którym powstały, różni ich faktyczna realizacja. Dlatego postaram się pokazać, że zasady obowiązujące w kibucach spowodowały, że takie wspólnoty w określonych warunkach funkcjonowały sprawnie ${ }^{5}$.

Naturalnie, nie tylko poszukiwanie idealnego rozwiązania organizacyjnego było przedmiotem zainteresowania przedstawicieli różnego rodzaju myśli utopijnej. Pojawiają się one w starożytnych i nowożytnych organizacjach religijnych, w specyficznych strukturach społecznych (na przykład różnego rodzaju komuny), w ideologii i praktyce ustrojów totalitarnych. Nad wszystkimi tymi formami i propozycjami „unosi się" pewien rodzaj perfekcjonizmu organizacyjnego (na wielu płaszczyznach), momentami tak kategoryczny jak w klasycznych utopiach. Stąd próba interpretacji kibucu jako formy organizacyjnej w kontekście tego typu myśli społecznej.

Neologizm „utopia” stworzył T. More. Słowo „utopia” składa się z greckiego przedrostka [ou], oznaczającego negację, i rzeczownika [topos] — miejsce, i oznacza „miejsce, którego nie ma"6. Oprócz wskazanego rozumienia tego słowa znajdujemy takie potoczne wyjaśnienia utopii, jak: ,plan, pomysł wzniosły, idealny, ale nieżyciowy, nierealny, nieziszczalny”7. Według Franiciszka Ryszki ,utopie to racjonalistyczne struktury myślenia, wykoncypowane przez teoretyków i intelektualistów, które zakładają idealny stan społeczeństwa. Teraźniejszość jest tedy poznawalna, a przyszłość dająca się urzeczywistnić"8. Jak pisał Jerzy Szacki, utopijne „będą [...] wszelkie systemy poglądów ugruntowane na sprzeciwie wobec aktualnie istniejących stosunków"9. Na przykład Georges Sorel wykorzystał opozycję mitu i utopii do określenia, czym ona jest, poddając ją krytyce ${ }^{10}$. Utopia jest według J. Szackiego, I. Pańków wizją nowego ładu społecznego. W państwie More’a „utopii miejsca”, w Nowej Harmonii R. Owena — ,utopii zakonu” — i w kibucach wszyscy byli równi i pracowali dla ogółu, a nie dla siebie, wszystko było uregulowane,

5 A. Lewin, op. cit., s. 20-21.

6 J. Szacki, Utopie, Warszawa 1968, s. 9.

7 W. Kotarbiński, Stownik mitów i tradycji kultury, Warszawa 1987, s. 1235.

8 F. Ryszka, Nauka o polityce. Rozważania metodologiczne, Warszawa 1984, s. 169.

9 J. Szacki, Spotkania z utopia, Warszawa 1980, s. 21. Szacki na stronach 48-49 za Chadem Walshemem (idem, From Utopia to Nightmare, London 1962, s. 71-73) wymienia następujące istotne cechy utopii: 1 . człowiek jest zasadniczo dobry; 2 . człowiek jest istotą plastyczną i łatwo ulega zmianie; 3. między pomyślnością jednostki a pomyślnością społeczeństwa nie istnieje sprzeczność; 4. człowiek jest istotą rozumną, co umożliwia ustanowienie w pełni racjonalnego ładu społecznego; 5. przyszłość jest całkowicie przewidywalna; 6 . szczęście na ziemi jest osiągalne; 7. ludzie nie mogą odczuwać znużenia szczęściem; 8. jest możliwe istnienie sprawiedliwych rządzących; 9. utopia nie jest zagrożeniem dla ludzkiej wolności, gdyż ta realizuje się w jej ramach.

10 I. Pańków, Filozofia utopii, Warszawa 1990, s. 192. Autorka uznała, że utopia jest tworem zbędnym, który jest tworzony w oderwaniu od rzeczywistości, powoduje zanik indywidualnego wysiłku moralnego, i jest tworzona przez ludzi oderwanych od rzeczywistości; ibidem, s. 193. 
nie pozostawiono dowolności w ich funkcjonowaniu ${ }^{11}$. W tych wspólnotach „,społeczeństwo ma przypominać niezawodnie funkcjonujący mechanizm" ${ }^{12}$. W tym wyrażał się totalny charakter tych organizacji.

Na potrzeby dalszych rozważań należy wskazać znaczenie słowa „racjonalność". Trzeba podkreślić, że termin ten można rozumieć wieloznacznie. Pochodzi od łacińskiego ratio — rozum, sposób, dowód, zasada. Najbliższym sensem łacińskiego ratio jest rajca, rozum, zasada. Racjonalność zaś pochodzi od rationalitis - to łacińskie słowo oznacza proporcję, miarę, związek i „organizację” tego, czego dotyczy. Racjonalność według Edmunda Morawca będzie układem poszczególnych części w całości, związkiem między tymi częściami, czyli powstaniem całości niezależnie od tego, czym ta całość jest ${ }^{13}$. Autor stwierdza, że słowo „racjonalność” należy „brać w dwóch znaczeniach — w znaczeniu rozumowości racji (racja ma charakter rozumowy) i w znaczeniu rozumności racji (racja ma charakter rozumny)" "14. Dalej stwierdza, że „rozumność” racji bierze się z jej „nieabsurdalności” ${ }^{15}$. Zwraca także uwagę, że słowo „racjonalność” to pojęcie historyczne i jego sens zmieniał się w określonych czasowo i przestrzennie warunkach. Natomiast „racjonalność” według Władysława Stróżewskiego można rozumieć, po pierwsze, jako pewną właściwość myślenia oraz działania, po drugie - jako „sensowność” (działanie racjonalne to takie, które ma sens, czyli zostało dobrze przemyślane i uzasadnione $)^{16}$. „Racjonalność” to określona właściwość myślenia, działania, które sprowadza się do celowości, ekonomiczności, sensowności i stanowi cechę metody, sposobu postępowania.

Dla potrzeb niniejszego artykułu „racjonalność” będzie oznaczać określony typ porządku lub porządkowania rzeczywistości. W tak rozumianej racjonalności za podstawę przyjęto rzeczowe jej rozumienie, przedstawione przez E. Morawca (zakłada istnienie racjonalności, która konstytuuje porządek i ład o charakterze koniecznym, wówczas mamy do czynienia z rozumnością przedmiotu) ${ }^{17}$,

11 J. Szacki, Utopie, Warszawa 1980, s. 52. Szacki w Spotkaniach... (s. 133-134) uznał, że w ,utopii zakonu” charakterystyczne jest, że „członkowie jej porzucają przyjęty przez większość sposób życia”, by stworzyć swój własny „wzorzec” będący „aktem negacji praktycznej” (s. 118).

12 S. Filipowicz, Historia myśli polityczno-prawnej, Gdańsk 2001, s. 159.

13 E. Morawiec, Wybrane filozoficzne koncepcje rozumu ludzkiego i racjonalność, Stare Kościeliska 2014, s. 157. Trzeba podnieść, że nie ma jednoznacznej definicji racjonalności. Dla przykładu podam tylko kilka z nich. Według Ryszarda Kleszcza „racjonalność” jest „,ech[a] obiektów racjonalnych” (idem, O racjonalności. Studium epistemologiczno-metodologiczne, Łódź 1998, s. 38), natomiast Mieszko Tałasiewicz poszukuje cech samej racjonalności „W odróżnieniu od cech przedmiotów racjonalnych" i poprzestaje na stwierdzeniu, iż racjonalność przedstawiana w tym sensie to zgodność z rozumem (idem, O pojęciu „racjonalności”: cz. 1, „Filozofia Nauki” 1995, nr 1-2, s. 98-99).
14 Ibidem.
15 Ibidem.
16 W. Stróżewski, Istnienie i sens, Kraków 1994, s. 396.
17 E. Morawiec, op. cit., s. 158. 
połączone z celowością postępowania twórców omawianych wspólnot, o której mówił W. Stróżewski ${ }^{18}$.

W celu pokazania racjonalności organizacji społeczeństwa w państwie T. More'a, komunie R. Owena i kibucach spróbuję wskazać zasady, które wprowadzały ład i porządek we wspólnotach i zależność pomiędzy tymi zasadami ${ }^{19}$. Następnie skupię się na tym, czy zasady, na których oparto wskazane organizacje społeczne, były konsekwencją przemyślanych i celowych działań jej twórców.

\section{Zasady wprowadzające ład i porządek}

\section{Organizacja przestrzeni}

Utopia to wyspa. Państwo założone przez króla Utopusa, który „zaraz w pierwszej wyprawie opanował ów kraj i ludność jego nieokrzesaną i dziką doprowadził do takiego stanu cywilizacji i kultury, że dziś potomkowie jej przodują niemal wszystkim narodom"20. Państwo składało się z pięćdziesięciu czterech miast i każde było urządzone tak samo i miało kształt prawie czworoboku. More na przykładzie stolicy państwa - Amaurotum - pokazał organizację przestrzeni każdej miejscowości w kraju. W celach obronnych były one otoczone wysokimi murami, a na zewnątrz murów był rów „ogrodzony kolczastym płotem” ${ }^{21}$. Plan był pomyślany tak, żeby ułatwiać przejazd przez miasto, które było podzielone ulicami na cztery części świata. W każdej z tych części na środku znajdował się rynek. W związku z tym, że w państwie nie było pieniędzy, na rynku mieszkańcy wymieniali się dobrami, które wyprodukowali. Był to wyraz sprzeciwu More'a wobec kapitalistycznego systemu produkcji, który rozwinął się w Anglii głównie w rolnictwie, a powodował ubożenie ${ }^{22}$.

Wzdłuż każdej ulicy stał gmach, w którym mieszkał filarcha wraz z rodziną, a po jednej i drugiej stronie budynku mieszkało po piętnaście rodzin. Na zewnątrz miasta były usytuowane cztery przestronne i dobrze zaopatrzone szpitale. Rzeźnie także znajdowały się poza miastem. Zakaz zajmowania się tą pracą przez Utopian wynikał z obawy utraty przez nich wrodzonej łagodności. Mieszkańcy wyspy sami nie zabijali zwierząt, te czynności wykonywali niewolnicy. Ponadto do każdego miasta był przydzielony określony obszar ziemi, którą uprawiali mieszkańcy wyspy.

18 K. Skurjat, Racjonalność jako wartość kulturowa, [w:] Spoleczeństwo a wojna. Kryzysy społeczne i konflikty kultur, red. M. Bodziany, Wrocław 2015, s. 9.

19 Ibidem, s. 160.

20 T. More, op. cit., s. 129.

21 Ibidem, s. 133.

22 A. Kowalska, Od utopii do antyutopii, Warszawa 1987, s. 17. 
Robert Owen również dokładnie zaplanował przestrzeń w osiedlu o charakterze rolniczo-przemysłowym ${ }^{23}$. Dla tego myśliciela kluczowe znaczenie miała wielkość gminy. Dlatego stwierdził, że najodpowiedniejszą liczbą mieszkańców było od ośmiuset do tysiąca dwustu osób ${ }^{24}$. Planem osiedla/gminy był czworobok podzielony na dwa prostokąty. Między tymi prostokątami znajdowała się kuchnia i jadalnia dla wszystkich jej mieszkańców oraz takie budynki, jak: ochronka dla dzieci, sala wykładowa, kaplica, szkoła, pomieszczenia administracyjne, biblioteka i świetlica. Przestrzeń wokół tych budynków miała być przeznaczona na place zabaw. Mieszkania znajdowały się na trzech bokach prostokątów, na jednym były sypialnie dla dzieci. Pośrodku czwartego boku znajdowały się mieszkania dla zarządzających. Na zewnątrz zabudowań mieściły się ogrody, farmy, pola, pastwiska ogrodzone żywopłotami i ogrody, a także browary, młyny, warsztaty i piekarnie ${ }^{25}$.

Organizacja kibuców również była określona i ,istniał [...] zamysł w planowaniu i budowaniu tych osiedli, mający sprzyjać realizacji wielorakich funkcji"26. Większość powstała według jednakowego planu przestrzennego ${ }^{27}$. Kibuce otaczały mury, mające chronić przed Arabami. Do środka można było się dostać bramą, której kiedyś pilnowali sami mieszkańcy, później zaś izraelscy żołnierze. Sprawdzani byli wszyscy. Centralny budynek to stołówka, która oprócz wiadomej funkcji odgrywała również rolę miejsca obrad mieszkańców ${ }^{28}$. Obszar mieszkalny obejmował domy (powierzchnia mieszkalna wynosiła $44-48 \mathrm{~m}^{2}$ ). Do pomieszczeń mieszkalnych przylegały szopy. Kibucnicy mieli też ogrody, domy dla dzieci i place zabaw dla każdej grupy wiekowej oraz pomieszczenia ogólnodostępne.

\section{Praca i jej organizacja}

Podstawą ekonomiczną społeczeństwa Utopii było rolnictwo. Mieszkańcy wyspy uprawiali ziemię, która przyznana była danemu miastu „do swojego użytku” i , ciągnęła się z każdej strony co najmniej na 12000 kroków”29. Obywatele poszczególnych miast nigdy nie mieli potrzeby poszerzania należących do

23 M.M. Jelenkowski, Owen, Warszawa 1981, s. 96.

24 R. Owen, Memoriat dla okręgu Lanark, [w:] M.M. Jelenkowski, op. cit., s. 236. Owen przed wyjazdem do Stanów Zjednoczonych zreformował zakład produkcyjny Lanark. Wprowadzone w nim zmiany miały na celu przede wszystkim zmniejszenie uciążliwości pracy robotników oraz dzieci, które do tej pory pracowały w fabryce po trzynaście godzin dziennie. Szerzej zob. M. Nicolson, I. Donnachie, The New Lanark highlanders: Migration, community, and language 1785-c.1850, „Family \& Community History” 2003, nr 6, s. 19-32.

25 M. Kieca, Ł. Kleska, Socjalizm utopijny Henri'ego Saint-Simona, Roberta Owena i Charlesa Fouriera, Rzeszów 2015, s. 84.

26 A. Lewin, op. cit., s. 41.

27 T. Czajkowski, Najbardziej udana porażka ze wszystkich utopii, „Scriptores” 2005, nr 3, s. 190-201. Autor opisał między innymi organizację przestrzeni w kibucu Baram.

28 A. Lewin, op. cit., s. 41.

29 T. More, op. cit., s. 130. 
danego miasta pól, ponieważ uważali się za ,włodarzy”, a nie właścicieli ziemi ${ }^{30}$. W momencie powstania państwa „ziemia, która dawniej robiła wrażenie nieurodzajnej, nie zaspokajała potrzeb jednego ludu, obecnie daje dostateczne utrzymanie i jemu, i przybyszom"31. Każdy musiał mieć wiedzę dotyczącą uprawy ziemi. Dotyczyło to mężczyzn i kobiet, a nawet dzieci, które uczyły się o tym w szkole lub przypatrywały się pracy na roli. Każdy musiał spędzić na wsi dwa lata, a później podejmował decyzję, czy nadal chce zajmować się rolnictwem, czy chce podjąć się innej pracy. Poza rolnictwem mieszkańcy parali się rzemiosłem. Do głównych rzemiosł More zaliczył: tkactwo, roboty murarskie, kowalskie i ciesielskie $^{32}$. Utopianie, bez względu na płeć, uczyli się jakiegoś rzemiosła. Jeśli któreś dziecko miało predyspozycje do wykonywania rzemiosła, którym jego rodzice się nie zajmowali, „wówczas jako przybrany syn przechodzi do jakiejś rodziny, która uprawia właśnie to rzemiosło"33. More ograniczył możliwość wyboru wykonywanego rzemiosła do kilku, wychodząc z założenia, że najistotniejsze są te, które zaspokajają podstawowe potrzeby ludzi. „Przecież głównym celem całego ustroju jest [...] zapewnienie wszystkim obywatelom jak największej ilości czasu, aby [...] mogli swobodnie poświęcać się kulturze duchowej"34.

W Utopii czas pracy był ściśle określony. Każdy pracował sześć godzin dziennie. „Trzy [godziny - A.G.] przed południem, po czym następuje pora obiadowa; po dwugodzinnym wypoczynku poobiednim pracują Utopijczycy znów trzy godziny i potem spożywają wieczerzę"35. Zdaniem More'a taka organizacja pracy była bardzo skuteczna i wystarczała do zaspokojenia wszystkich potrzeb bytowych mieszkańców.

W założonej przez Owena komunie rolnictwo również miało ogromne znaczenie. Wokół New Harmony znajdowały się pola uprawne. W związku z rozwojem przemysłowym oraz wcześniej wykonywaną przez Owena pracą (był właścicielem i zarządcą fabryki włókienniczej) oprócz rolnictwa istniały także fabryki produkcyjne. Miały one odciążyć i tak — zdaniem myśliciela — ciężko pracujących ludzi. Od 1817 roku Owen propagował hasło wprowadzenia ośmiogodzinnego dnia pracy, ośmiogodzinnego odpoczynku i ośmiogodzinnego snu. Jako przeciwnik wyzysku dzieci i robotników zabronił zatrudniania w fabrykach dzieci do dziesiątego roku życia oraz skrócił czas pracy do dziesięciu godzin dziennie $^{36}$. Nie wiadomo jednak, dlaczego jako zwolennik industrializacji w no-

30 Ibidem.

31 Ibidem, s. 142.

32 Ibidem, s. 136.

33 Ibidem.

34 Ibidem, s. 141.

35 S. Klonowicz, op. cit., s. 20.

$36 \mathrm{~W} 1806$ roku na sesji parlamentu angielskiego R. Owen wezwał do uregulowania kwestii pracy dzieci i zastrzegł, że żadne dziecko poniżej dziesiątego roku życia nie może być zatrudnione w fabrykach. Izba Gmin podjęła tę kwestię, ale jej ostateczne uregulowanie zajęło cztery lata. Zob. E. Smith Denehie, T. Haute, The Harmonist Movement in Indiana, „Indiana Magazine of History” 
wej gminie nie przewidywał używania maszyn rolniczych ${ }^{37}$. Organizacja pracy stworzona w New Harmony miała zapewnić samowystarczalność jej mieszkańców. W celu zapewnienia pracownikom motywacji Owen ustanowił system ,pieniędzy w czasie", co oznaczało, że waluta miała równowartość czasu, w którym pracownik wytworzył produkt i mógł go wymienić na towary o podobnej ilości czasu pracy.

Podobnie jak w Utopii i New Harmony rolnictwo przez lata było podstawą funkcjonowania kibuców. Na początku brakowało rąk do pracy, trzeba podkreślić, że bardzo ciężkiej. Przed przyjazdem na terytorium późniejszego Izraela Żydzi nie uprawiali ziemi i nie hodowali bydła. Jednak w związku z chęcią utworzenia własnego państwa twórcy idei syjonistycznej uważali, że nie da się tego zrobić bez przejęcia we władanie ziemi. Drugą istotną przeszkodą w uprawie roli przez kibucników były problemy z nawodnieniem terenów uprawnych, ponieważ późniejsze państwo Izrael leży na krawędzi pasa pustynnego ${ }^{38}$.

Etyka pracy miała bardzo duże znaczenie w kibucach. Praca była wartością samą w sobie. Wielki nacisk kładziono na pracę fizyczną, głównie na rolii ${ }^{39}$. W rolnictwie pracowali mężczyźni i kobiety, z przerwą na wspólny posiłek. Członkowie kibucu pracowali również w stołówkach, jadalni czy kuchni, jednak tutaj obowiązywał system rotacyjny. W późniejszych czasach ludzie podejmowali pracę zgodnie ze swoimi umiejętnościami i wykształceniem, ale nie zdarzało się to wśród mieszkańców pierwszych kibuców ${ }^{40}$. Zasadą była praca przez osiem godzin dziennie, od poniedziałku do soboty, przy czym w piątek pracowano sześć godzin.

\section{Sposoby podejmowania decyzji i sprawowania władzy}

W Utopii władze pochodziły z wyborów. Trzydzieści rodzin wybierało filarchów, trzysta rodzin podlegało władzy zwierzchnika, to jest protofilarchy, wszyscy protofilarchowie (w liczbie dwustu) wybierali księcia spośród czterech kandydatów wskazanych przez lud. Był też senat, który decydował o sprawach całej Utopii. Natomiast w każdym mieście istniały rady, które „zarządzały całym życiem i rozstrzygały wszystkie sprawy okręgowe"41. System opierał się na w pełni demokratycznych wyborach, w których uczestniczyli wszyscy Utopianie.

19, 1923, nr 2, s. 192, https://scholarworks.iu.edu/journals/index.php/imh/article/view/6286/6289 (dostęp: 7.09.2018).

37 M.M. Jelenkowski, op. cit., s. 101.

38 Problemy rozwiązało dopiero połączenie w 1964 roku większości słodkowodnych zasobów w zintegrowany system Narodowego Systemu Transportu Wody; Izrael w faktach, przeł. L. Polak, red. E. Hirsch, Jerozolima 1996, s. 85.

39 M. Harris, The kibbutz: Uncovering the utopian dimension, „Utopian Studies” 1999, nr 10 (1), s. 122.

40 A. Lewin, op. cit., s. 43. Autor stwierdził, że obecnie (rok wydania książki: 1992) na roli pracuje jedynie $17 \%$ kibucników.

41 S. Klonowicz, op. cit., s. 18. 
Owen również stworzył organizację aparatu zarządzania w New Harmony, która w ciągu trzech lat istnienia wspólnoty okazała się nietrwała. Zebranie Ogólne było prawodawczym organem w New Harmony. Prawo głosu mieli mieszkańcy, którzy ukończyli dwadzieścia jeden lat, kworum stanowiło jedną szóstą ogólnej liczby uprawnionych w przypadku podejmowania uchwał biznesowych ${ }^{42}$. Zebranie Ogólne mieszkańców było zwoływane przez Komitet i podejmowało uchwały większością głosów. Zebranie Ogólne wyrażało zgodę na przyjęcie nowych członków większością dwóch trzecich głosów ${ }^{43}$. Lokalna gazeta „New Harmony Gazette" publikowała sprawozdania z zebrań. Komitet był organem wykonawczym i miał zajmować się wszystkimi sprawami społeczności ${ }^{44}$. Był zobowiązany do składania Zgromadzeniu Ogólnemu cotygodniowych raportów z wykonanej pracy. Na czele Komitetu stał Owen (od uchwalenia trzeciej konstytucji ${ }^{45}$ ), a w jego skład wchodzili sekretarz, skarbnik, komisarz komuny oraz osoby stojące na czele najważniejszych departamentów ${ }^{46}$. Owen przewidział także powołanie sześciu tematycznych departamentów: gospodarstwa wiejskiego, przemysłu i mechaniki, nauki i oświaty, literatury, ekonomiki ogólnej oraz gospodarstwa domowego ${ }^{47}$.

W kibucach wszystkie decyzje podejmował ogół członków. Wszyscy mieszkańcy, którzy ukończyli osiemnaście lat, mieli jeden głos na zebraniu członków wspólnoty. Rozstrzygnięcia zapadały większością głosów. Najczęściej zebrania odbywały się raz w tygodniu, w sobotę, a miejscem spotkania była stołówka. $\mathrm{Na}$ zebraniu można było poruszać wszelkie sprawy dotyczące społeczności i kibucu. Najistotniejsze kwestie to uchwalenie budżetu oraz przyjmowanie nowych członków. Zebranie służyło nie tylko podejmowaniu decyzji w wyniku głosowania, lecz także stanowiło forum, na którym członkowie mogli wyrażać swoje opinie i poglądy. Decyzje podjęte w czasie zebrania wykonywał kilkuosobowy zarząd, którym kierował jeden lub dwóch sekretarzy. Zarząd reprezentował kibuc na zewnątrz. Wraz z sekretarzami wybierany był na rok lub dwa lata. Tak częsta rotacja miała uchronić członków zarządu przed zdemoralizowaniem ${ }^{48}$. Uczestnictwo

42 Art. 4 Constitution of the New Harmony Community of Equality, „The New Harmony Gazette" 1826, nr 21, s. 162, https://babel.hathitrust.org/cgi/pt?id=uc1.31175008411889;view=1 up; seq=175;size=175 (dostęp: 11.09.2018). Zob. M.M. Jelenkowski, op. cit., s. 109.

43 Constitution of the New Harmony agricultural and pastoral society, ,The New Harmony Gazette" 45, 1826, s. 362, https://babel.hathitrust.org/cgi/pt?id=umn.319510007329860;view=1up ;seq=374;size=150 (dostęp: 10.09.2018).

44 The Constitution of the preliminary society of New-Harmony, „The New Harmony Gazette" 1, 1825, s. 3, https://babel.hathitrust.org/cgi/pt?id=uc1.31175008411889; view=1up;seq= 14;size $=150$ (dostęp: 10.09.2018).

45 Constitution of The New Harmony agricultural..., s. 362.

46 M.M. Jelenkowski, op. cit., s. 109.

47 Art. 5 Constitution of The New Harmony Community..., s. 162.

48 K. Hołda, Kibuc dawniej i dziś, „Obyczaje” 2004, nr 17, s. 20. 
w zebraniach było prawem, a nie obowiązkiem kibucników. W związku z tym, że w każdym kibucu było organizowane zebranie, mogło ono we wszelkich sprawach podejmować autonomiczne decyzje ${ }^{49}$.

\section{Wspólna własność}

W Utopii More stwierdził, że eliminacja własności prywatnej dała możliwość powstania „najlepszego ustroju" ${ }^{20}$. Pisał: „Jestem więc mocno o tym przekonany, że zupełne zniesienie prawa własności jest jedynym środkiem do równego i sprawiedliwego podziału dóbr i do zapewnienia ludziom szczęścia"51.

Ponieważ własność prywatna negatywnie wpływała na ludzi i na możliwości ekonomiczne państwa, w Utopii wszystko było wspólne. Przez wspólną własność realizowano zasadę wolności i sprawiedliwości. Oznaczało to, że Utopianie otrzymywali wszelkie dobra w zależności od potrzeb. Wszyscy byli równi i zaopatrując się na rynku, każdy mógł dostać to, czego mu brakowało. Sprawiedliwość to równość majątkowa wszystkich mieszkańców wyspy. Wszelkie zło wynikało — zdaniem autora Utopii — z nierówności materialnych między ludźmi. W celu eliminacji podziału społeczeństwa na biednych i bogatych Utopianie nie używali pieniędzy, „zachowują je na wypadek chwil krytycznych, które mogą zajść lub nigdy nie nastąpią" ${ }^{2}$. Zaopatrzenie w potrzebne rzeczy — od żywności po rzeczy do pracy, ubrania itp. - mieszkańcy zapewniali sobie poprzez wytworzenie odpowiedniej liczby niezbędnych produktów.

Owen w celu założenia New Harmony 3 stycznia 1825 roku zakupił miasto od Georga Rappa za prawie 150 tysięcy dolarów ${ }^{53}$. Utworzył w nim osiedle rolniczo-produkcyjne, które miało się opierać na własności kolektywnej ${ }^{54}$. Dla Owena własność prywatna w otaczających go realiach kapitalizmu była źródłem wszelkiego zła i doprowadziła do ubożenia społeczeństwa i wyzysku ludzi. Był zdania, że

49 W kibucu Baram po drugiej wojnie światowej przyjęto uchwałę, w której zakazano Niemcom być wolontariuszami. Była to decyzja podjęta dawno temu, prawdopodobnie w latach sześćdziesiątych XX wieku, jednak od tamtej pory zebranie jej nie zmieniło. Można przypuszczać, że miało to związek z mieszkańcami kibucu, którzy przeżyli Holokaust i nie chcieli słyszeć języka niemieckiego, ponieważ kojarzył im się z traumatycznymi wydarzeniami; T. Czajkowski, op. cit., s. $197-198$.

50 T. More, op. cit., s. 81.

51 Ibidem, s. 123.

52 Ibidem, s. 150.

53 D.F. Carmony, J.M. Elliott, New Harmony, Indiana: Robert Owen's seedbed for utopia, „Indiana Magazine of History” 76, 1980, nr 3, s. 212. R. Owen jako twórca idei New Harmony nie działał w niej sam, miał partnera - Williama Mclure, który pomagał mu w jej tworzeniu i organizacji.

54 The Constitution of the preliminary..., s. 3. W preambule do konstytucji Owen napisat: „Społeczeństwo zostało utworzone dla polepszenia charakteru jego członków i warunków, w jakich żyją i w celu przygotowania ich do życia we wspólnocie i posiadania wspólnej własności”. Ibidem. 
interes ogólny silniej pobudzał do intensywnej pracy niż interes indywidualny ${ }^{55}$. Wspólna własność miała zapewnić dobrobyt społeczny. Owen uznał, że bogactwo powstałe w wyniku pracy na roli czy w fabrykach powinno być dzielone na podstawie zasady równości. Wypracowany dochód miał stanowić wspólną własność i każdy mieszkaniec New Harmony miał zapewniony dostęp do potrzebnych mu artykułów w celu zaspokojenia swoich uzasadnionych potrzeb ${ }^{56}$. Owen był bowiem zdania, że wszyscy mają do tego prawo, ale tylko w podstawowym zakresie. Nadmiar gromadzonych dóbr prowadził do rozwarstwienia materialnego mieszkańców.

W kibucach również nie było prywatnej własności ${ }^{57}$. Ziemia, na której usytuowane były i są kibuce, formalnie należy do państwa, a nie do członków wspólnoty, którzy byli jej posiadaczami. W kibucach wszystkie obiekty mieszkalne, gospodarcze i użyteczności ogólnej, narzędzia, sprzęt i maszyny rolnicze oraz uprawy i dobytek hodowlany stanowiły wspólną własność członków. Członkowie wspólnoty dobrowolnie odeszli od własności prywatnej ${ }^{58}$. Wynagrodzenie pracowników także było wspólną własnością, kibucnicy otrzymywali jedynie małą ilość pieniędzy na drobne wydatki. Trzeba pamiętać, że w pierwszych latach istnienia kibuców mieszkańcy mieli zapewnione wyżywienie, ponieważ uprawiali rolę i hodowali zwierzęta.

\section{Edukacja}

W Utopii funkcjonował system powszechnego nauczania we własnym języku. Podstawową umiejętnością, którą musiał opanować każdy, była uprawa roli. Dzieci, które miały „niezwykłe zdolności, niepospolity rozum i pęd do wiedzy”, zajmowały się nauką ${ }^{59}$. Najwyższe urzędy, do których zaliczano między innymi posłów i kapłanów, sprawowali ludzie uczeni, co wyraźnie pokazuje stosunek Utopian do wykształcenia i samej nauki. Mieszkańcy Utopii uczyli się przede wszystkim języków, medycyny, fizyki i filozofii oraz etyki. Bardzo charakterystyczne było nieustanne poszukiwanie doskonalszych rozwiązań w rolnictwie. Gotowość i łatwość przyswajania sobie nowych wynalazków i maksymalne ich wykorzystywanie miało usprawnić pracę. Naukowcy w Utopii, jak stwierdził Rafał Hytlodeusz, nie mieli zamiłowania do abstrakcji, logiki formalnej i prawa. Osiągnęli bardzo dużo w dziedzinie muzyki, dialektyki, arytmetyki i geometrii. Trzeba również podkreślić, że większość społeczeństwa w wolnych chwilach uczęszczała na wykłady, które odbywały się rano. Dzieci od małego wychowywały się i mieszkały z rodzicami.

55 W.P. Wołgin, Szkice o zachodnioeuropejskim socjalizmie utopijnym, Warszawa 1989, s. 79.

56 Ibidem, s. 102.

57 M. Harris, op. cit., s. 122.

58 A. Lewin, op. cit., s. 36.

59 Ibidem, s. 154. 
Organizacja nauki u Owena wynikała z jego założenia, że człowiek jest kształtowany przez środowisko:

Nie ulega najmniejszej wątpliwości, że gdyby niektórzy z ludzi skazanych na śmierć wyrokami dzisiejszych sędziów urodzili się, wychowali i żyli w takich warunkach, w jakich urodzili się, wychowali i żyli owi sędziowie, to niejeden z nich wydawałby takie same straszne wyroki na wysoce dzisiaj szanowanych dygnitarzy sprawiedliwości ${ }^{60}$.

Owen uważał bowiem, że podstawą nie powinna być rodzina, lecz wspólnota, kolektyw, który miał wychowywać i kształtować dzieci w duchu harmonii społecznej.

System edukacji powinien prowadzić do tego, aby dzieci przez niego kształtowane pojmowały dobro i zło jako naturalną konsekwencję swojego postępowania, a nie żeby uważały konkretne zachowania za dobre lub złe, dlatego że są za nie nagradzane lub karane przez instytucje społeczne ${ }^{61}$.

We wspólnocie dokładnie zaplanowano proces edukacji ${ }^{62}$. Wszystkie dzieci rozpoczynały naukę w wielu pięciu lat, jako siedmiolatki zaczynały uczyć się praktycznej wiedzy (na przykład zostawały pomocnikami w ogrodzie), a w wieku dwunastu lat zaczynały przyuczać się do wykonywania przyszłego zawodu. Nauka miała się opierać przede wszystkim na metodzie poglądowej i obserwacji, a nie nauce $\mathrm{z}$ książek ${ }^{63}$. Zasadą była nauka do dwudziestego roku życia, a ponadto starsi mieszkańcy New Harmony mogli brać udział w kursach dokształcających. Model przyjęty przez Owena był bardzo liberalny, nie przewidywał kar ${ }^{64}$.

W kibucach jedną z podstawowych zasad była wspólna edukacja i opieka nad dziećmi. Jak pisze Michael Harris, „obowiązki dotyczyły nauczania i szkolenia we wspólnotowym sposobie życia" ${ }^{65}$. Dzieci mieszkały razem we wspólnych domach. Trafiały tam już trzeciego dnia po porodzie, a matki mogły przychodzić w określonych godzinach, żeby je nakarmić. Starsze dzieci po szkole przychodziły na parę godzin do domów rodziców, a na noc wracały do domów dla dzieci ${ }^{66}$. Dzięki takiemu rozwiązaniu, które dziś wydaje się bezduszne, rodzice mogli skupić się na pracy. Taki system funkcjonował latami. Dzieci wychowywane były zbiorowo i uczyły się w kibucowych żłobkach, przedszkolach i szkołach podstawowych, rodzice nie mieli wpływu na ich wychowanie. W pierwszych kibucach wynikało

60 R. Owen, Wybór pism, przeł. M. Przyborowska, Kraków 1959, s. 43-44.

61 S. Ziembicki, Spory wokót doktryny Roberta Owena, ,Przegląd Prawa i Administracji” 78, 2008, s. 187.

62 K. Szumkiewicz, Konstrukcje nadziei w utopiach pedagogicznych Owena i Fouriera, „Kultura i Wychowanie” 2011, nr 1, s. 113.

63 W.P. Wołgin, op. cit., s. 81.

64 J. Rick, Teaching New Harmony: Education, religion and human nature at New Harmony, Indiana, 1824-1827, „Primary Source” 5, 2015, nr 2, s. 8 n.

65 M. Harris, op. cit., s. 122.

66 A. Zagner, Rozmowa o izraelskich kibucach. To byt mój dom, http://www.polityka.pl/tygodnikpolityka/kultura/1565945,1,rozmowa-o-izraelskich-kibucach.read (dostęp: 21.07.2017). 
to $\mathrm{z}$ tego, że każde ręce były potrzebne do pracy przy ich budowie ${ }^{67}$. Od przedszkola system edukacyjny kładł nacisk na współpracę w życiu codziennym. Od klas wczesnoszkolnych młodzież otrzymywała zadania i musiała podejmować decyzje mające wpływ na grupę, natomiast dalszą edukację odbywała w miastach na koszt kibuców. Ponadto podstawową umiejętnością kibucników była obrona, dlatego zarówno kobiety, jak i mężczyźni odbywali obowiązkową służbę wojskową.

\section{Zależność zasad obowiązujących we wspólnotach}

Elementy łączące opisane wspólnoty były od siebie zależne i wpływały na ich właściwe funkcjonowanie. We wszystkich społecznościach podstawą było bezpieczeństwo mieszkańców, które zapewniał ład przestrzenny wprowadzony we wszystkich miastach w Utopii, w New Harmony i w kibucach. Miał on także ułatwiać życie mieszkańców.

W tak zorganizowanej przestrzeni w Utopii, New Harmony i pierwszych kibucach ekonomiczną i egzystencjalną podstawą społeczności było rolnictwo. Zarówno Utopianie, Harmoniści, jak i kibucnicy kładli nacisk na poznanie podstaw rolnictwa (stanowiącego we wszystkich wspólnotach fundament życia członków) i edukację ogólną. Krzewienie określonych zasad było charakterystyczne w trzech wspólnotach. Ich twórcy zakładali, że „,człowiek nie kształtuje się sam, ani swojego charakteru ani uczuć, ani opinii i wierzeń, ale znajduje się pod przemożnym wpływem środowiska, rodziny, wychowawców" ${ }^{98}$. Zadaniem było wpojenie fundamentalnych wartości, na których opierało się funkcjonowanie wspólnot. Procesy edukacji i wychowania miały nie tylko zmienić zachowania członków, lecz także „kreować rzeczywistość na wzór własnych [twórców - A.G.] idei”69. W celu zapewnienia wszystkich potrzebnych do egzystencji rzeczy (od jedzenia, przez ubrania, do narzędzi) praca była obowiązkiem powszechnym. Był to element niezbędny do istnienia i rozwoju, a przede wszystkim do zapewnienia dobrobytu mieszkańców. Powszechny obowiązek pracy był elementem warunkującym porządek w społeczeństwie. Ta wartość gloryfikowana jest we wszystkich omawianych wspólnotach ${ }^{70}$. Wszelkie dobra uzyskane z pracy były wspólną własnością członków wspólnot. Równość materialna miała zapewnić jednakowy poziom życia mieszkańców i likwidację nieporozumień na tle majątkowym. Miało to wyeliminować wady ludzi, takie jak chciwość czy zazdrość. Nie mniej ważnym elementem była władza. We wszystkich wspólnotach zarządzali i decydowali mieszkańcy, był to wyraz ich równości. Mieszkańcy dokonywali wyboru w drodze demokracji pośredniej (Utopia - wybór filarchów, następnie wybór

67 A. Lewin, op. cit., s. 62.

68 L. Kołakowski, Główne nurty marksizmu, t. 1, Warszawa 2009, s. 191.

69 Ł. Stefaniak, Utopizm. Źródła myślowe i konsekwencje cywilizacyjne, Lublin 2011, s. 104.

70 Ibidem, s. 107. 
protofilarchów) lub bezpośredniej (Zgromadzenie Ogólne u Owena, w kibucach zebrania członków wspólnoty).

Zasady, na których oparto omawiane wspólnoty, tworzyły łańcuch zależności od właściwego wychowania, edukacji, pracy, wspólnej własności, zapewnienia bezpieczeństwa, po władzę. Jeśli choć jeden z elementów nie współgrał z innymi, dochodziło do zerwania więzi we wspólnocie, która już nie funkcjonowała tak, jak zakładali jej pierwotni twórcy ${ }^{71}$.

\section{Celowość działań twórców wspólnot}

Działalność More'a, Owena i kibucników wynikała ze sprzeciwu wobec zastanej rzeczywistości. Przyczyny tej niezgody miały różne podłoże. Były konsekwencją analitycznego podejścia do zastanych warunków, a celem, jaki przyświecał ich twórcom, było stworzenie wspólnot „wyrastających z poszukiwania ustroju zgodnego z ponadhistorycznymi wymogami rozumu"72. Autorzy, biorąc za podstawę krytykę i sprzeciw wobec warunków życia, stworzyli: ideę (T. More), New Harmony (R. Owen) i kibuce.

Jak zauważa Irena Pańków, „utopia Morusa stanowi pochwałę rozumu, pochwałę praw układanych podług rozumnych i naturalnych zasad naczelnych"73. Książka stanowiła krytykę panującej w Anglii w XVI wieku monarchii Tudorów i wyzysku klas niższych przez wyższe. Kryzys miał wymiar gospodarczy, społeczny i polityczny ${ }^{74}$. Gospodarczo wyrażał się w osłabieniu dominacji gospodarki naturalnej na rzecz produkcji towarowej; społecznie w naruszeniu obowiązującego dotychczas ładu społecznego; politycznie w osłabieniu wpływu religii na władzę ${ }^{75}$.

New Harmony powstała w wyniku sprzeciwu Owena wobec kapitalizmu, z którego jego zdaniem wynikały wszelkie społeczne i gospodarcze nierówności. Jak pisał Leszek Kołakowski, „,ele Owena były praktyczne: usunięcie nędzy, bezrobocia, przestępczości i wyzysku"76. Stworzenie wspólnoty miało wyeliminować te szkodliwe zjawiska. Owen stworzył azyl, w którym chciał zachować własną odrębność.

Kibuce powstały, ponieważ Żydzi uciekali przed prześladowaniami i niesprawiedliwością, która spotkała ich w Rosji, ale nie tylko. Ich wyjazd do

71 Kibuce powstałe po 1930 roku zaczęły odchodzić od wspólnej własności, od wspólnego wychowania dzieci z małym udziałem rodziców czy od ograniczania wolności wyboru pracy przez członków wspólnoty.

72 J. Szacki, Spotkania..., s. 112.

73 I. Pańków, op. cit., s. 37.

74 Ibidem, s. 41-42.

75 Ibidem, s. 42.

${ }^{76}$ L. Kołakowski, op. cit., s. 191. 
późniejszego Izraela był podyktowany również chęcią stworzenia lepszego świata dla siebie i potomnych. Osiedlili się w miejscu, które choć nieprzyjazne, dało im bezpieczeństwo. Dzięki przyjętym zasadom i ciężkiej pracy pionierom udało się stworzyć wspólnoty, które istniały latami. Mimo zasad tożsamych z utopią More'a czy utopijnym socjalizmem Owena różnica w pierwszych kibucach polegała na tym, że realne zagrożenie życia jej członków spowodowało chęć stworzenia lepszego świata. Nie był to plan twórcy idei, lecz praktyczna realizacja podyktowana pragnieniem przeżycia.

\section{Podsumowanie}

Nie można z całą pewnością stwierdzić, czy państwo More'a miało szansę powodzenia, czy było skazane na porażkę. Była to tylko idea. Jednak nieprzestrzeganie wskazanych zasad stało się przyczyną upadku Owenowskiej społeczności. Brak realizacji idei wynikał z postępowania mieszkańców wspólnoty. Chociaż miejsce, które zakupił Owen, było wcześniej dobrze prosperującą komuną, założoną przez niemieckiego księdza G. Rippa, po trzech latach upadło. Jedną z przyczyn niepowodzenia było negowanie przez część mieszkańców wspólnej własności. Trzeba pamiętać, że wśród ośmiuset osób, które na początku brały udział w przedsięwzięciu angielskiego przemysłowca, była elita intelektualna, która nie przywykła do ciężkiej pracy po dziesięć godzin dziennie. Nie podobało się to ciężko pracującym mieszkańcom, dzięki którym wspólnota miała zapewnione podstawowe produkty ${ }^{77}$. Równość członków komuny okazała się fikcją, z czego Owen nie zdawał sobie sprawy. Członkowie wspólnoty po początkowej fascynacji zasadami i wartościami, na których powstała, przestali w nie wierzyć. Pragnienie posiadania okazało się silniejsze od pragnienia współposiadania (współwłasności) ${ }^{78}$. Przyczyną upadku był również brak jednoznacznego przywództwa. Z jednej strony było Zgromadzenie Ogólne podejmujące decyzje, a z drugiej Owen, który był właścicielem New Harmony i twórcą wspólnoty. Idealistycznie wyszedł on z założenia, że po przedstawieniu zasad wszyscy będą się do nich stosować. Realizacji jego założeń nie sprzyjały też jego częste wyjazdy z New Harmony, ponieważ nie widział zachodzenia negatywnych zmian i nie mógł w porę na nie reagować. New Harmony w pewnym momencie stała się przeludniona i do utrzymania wszystkich członków nie wystarczało towarów wyprodukowanych we wspólnocie. Zasady jedynie deklarowane, a nie przestrzegane nie wystarczyły do przetrwania wspólnoty.

77 Conlin J.R., The American Past: A Survey of American History, t. 2, Enhanced Edition, Belmont 2009.

78 B. Danowska-Prokop, Własność w poglądach przedstawicieli socjalizmu utopijnego, „Studia Ekonomiczne. Zeszyty Naukowe Uniwersytetu Ekonomicznego w Katowicach” 2016, nr 260, s. 25. 
Inaczej przez lata wyglądało to w kibucach. Wszystkie zasady tworzyły całość i decydowały o właściwym funkcjonowaniu wspólnoty. Kibuce oparte na wspomnianych fundamentach przez lata działały w niezmienionej formie. W 1910 roku powstał pierwszy kibuc, a w roku 1930 było ich już dwadzieścia dziewięć ${ }^{79}$. Jak pisał A. Lewin, „dla starszych generacji, generacji pionierów, kibuc był ucieleśnieniem porywającej idei, niezwykłej wizji, [...] w ich systemie wartości najwyższą wartość stanowiła wspólnota" $" 80$.

\section{Bibliografia}

Carmony D.F., Elliott J.M., New Harmony, Indiana: Robert Owen's seedbed for utopia, „Indiana Magazine of History" 76, 1980, nr 3.

Constitution of the New Harmony agricultural and pastoral society, „The New Harmony Gazette” 45, 1826, https://babel.hathitrust.org/cgi/pt?id=umn.319510007329860;view=1up;seq=374;si$\mathrm{ze}=150$.

Constitution of the New Harmony Community of Equality, „The New Harmony Gazette” 1826, nr 21, https://babel.hathitrust.org/cgi/pt?id=uc1.31175008411889; view=1up;seq=175;size=175.

Constitution of the preliminary society of New-Harmony, „The New Harmony Gazette” 1, 1825, https://babel.hathitrust.org/cgi/pt?id=uc1.31175008411889;view=1up;seq=14;size=150.

Conlin J.R., The American Past: A Survey of American History, t. 2, Enhanced Edition, Belmont 2009.

Czajkowski T., Najbardziej udana porażka ze wszystkich utopii, „Scriptores” 2005, nr 3.

Danowska-Prokop B., Własność w poglądach przedstawicieli socjalizmu utopijnego, „Studia Ekonomiczne. Zeszyty Naukowe Uniwersytetu Ekonomicznego w Katowicach” 2016, nr 260.

Duda K., Ruch kibucowy w Izraelu w latach 1948-1989: utopia w działaniu, [w:] Żydzi, Izrael i Palestyńczycy. Dzieje, stan obecny, perspektywy, red. S. Czapnik, G. Omelan, Opole 2016.

Filipowicz S., Historia myśli polityczno-prawnej, Gdańsk 2001.

Frister R., Kibuc w luce, http://www.polityka.pl/tygodnikpolityka/swiat/1504426,1,kibuc-ktoryzyje-z-produkcji-sprzetu-wojskowego.read.

Harris M., The kibbutz: Uncovering the utopian dimension, „Utopian Studies” 1999, 10 (1).

Hołda K., Kibuc dawniej i dziś, „Obyczaje” 2004, nr 17.

http://teatrnn.pl/leksykon/artykuly/alex-dancyg-ur-1948/.

http://robert-owen-museum.org.uk/home.

Izrael w faktach, przeł. L. Polak, red. E. Hirsch, Jerozolima 1996.

Jelenkowski M.M., Owen, Warszawa 1981.

Kieca M., Kleska Ł., Socjalizm utopijny Henri'ego Saint-Simona, Roberta Owena i Charlesa Fouriera, Rzeszów 2015.

Kleszcz R., O pojęciu „racjonalności”: cz. 1, „Filozofia Nauki” 1995, nr 1-2, s. 98-99.

Kleszcz R., O racjonalności. Studium epistemologiczno-metodologiczne, Łódź 1998, s. 38.

Klonowicz S., ,,Utopia” Tomasza Morusa, Kraków 1919.

Kautsky K., Tomasz More i jego utopia, Warszawa 1949

Kołakowski L., Główne nurty marksizmu, t. 1, Warszawa 2009.

Kotarbiński W., Stownik mitów i tradycji kultury, Warszawa 1987, s. 1235.

Kowalska A., Od utopii do antyutopii, Warszawa 1987.

79 A. Lewin, op. cit., s. 22.

80 Ibidem, s. 84.

Studia nad Autorytaryzmem i Totalitaryzmem 41, nr 2, 2019

(C) for this edition by CNS 
Leksykon politologii, red. A. Antoszewski, R. Herbut, Wrocław 2000.

Lewin A., Kibuce w Izraelu. Utopia czy rzeczywistość, Warszawa 1992.

Morawiec E., Wybrane filozoficzne koncepcje rozumu ludzkiego i racjonalność, Stare Kościeliska 2014.

More T., Utopia, przeł. K. Abgarowicz, wprow. W. Ostrowski, Warszawa 1954.

Near H., The Kibbutz Movement: A History, Oxford 1992.

Nicolson M., Donnachie I., The New Lanark highlanders: Migration, community, and language 1785-c.1850, „Family \& Community History” 2003.

Owen R., Wybór pism, przeł. M. Przyborowska, Kraków 1959.

Pańków I., Filozofia utopii, Warszawa 1990.

Piątkowska A., Kibuc - wcielona utopia, http://www.styl.pl/magazyn/news-kibuc-wcielona-utopia,nId,1463344.

Rick J., Teaching New Harmony: Education, religion and human nature at New Harmony, Indiana, 1824-1827, „Primary Source” 5, 2015, nr 2.

Ryszka F., Nauka o polityce. Rozważania metodologiczne, Warszawa 1984.

Sand S., Kiedy i jak wynaleziono ziemię Izraela. Od Ziemi Świętej do ojczyzny, Warszawa 2015.

Skurjat K., Racjonalność jako wartość kulturowa, [w:] Społeczeństwo a wojna. Kryzysy społeczne $i$ konflikty kultur, red. M. Bodziany, Wrocław 2015.

Smith Denehie E., Haute T., The Harmonist Movement in Indiana, „Indiana Magazine of History” 2, 1923, nr 19, https://scholarworks.iu.edu/journals/index.php/imh/article/view/6286/6289.

Stefaniak Ł., Utopizm. Źródła myślowe i konsekwencje cywilizacyjne, Lublin 2011, s. 104.

Stróżewski W., Istnienie i sens, Kraków 1994.

Szacki J., Spotkania z utopia, Warszawa 1980.

Szacki J., Utopie, Warszawa 1968.

Szumkiewicz K., Konstrukcje nadziei w utopiach pedagogicznych Owena i Fouriera, „Kultura i Wychowanie" 2011, nr 1.

Świętochowski A., Utopie w rozwoju historycznym, Warszawa 1910.

Wołgin W.P., Szkice o zachodnioeuropejskim socjalizmie utopijnym, Warszawa 1989.

Walsh Ch., From Utopia to Nightmare, London 1962.

Zagner A., Rozmowa o izraelskich kibucach. To był mój dom, http://www.polityka.pl/tygodnikpolityka/kultura/1565945,1,rozmowa-o-izraelskich-kibucach.read.

Ziembicki S., Spory wokót doktryny Roberta Owena, „Przegląd Prawa i Administracji” 78, 2008.

\section{IN SEARCH OF A RATIONAL ORGANIZATION OF SOCIETY: THOMAS MORE, ROBERT OWEN AND THE PRACTICE OF THE KIBBUTZES}

The aim of the article is to present and analyze selected organizational solutions based on the same principles thanks to which their creators wanted to create the perfect social order. I will try to demonstrate the rationality of these solutions using the example of the state of T. More, New Harmony of R. Owen and kibbutzes in Israel. Certain regularities can be observed in that the emergence of fundamental assumptions of these communities coincides with the moments of crisis in particular societies, which led to changes in the way people think about the world around them. The object of the research is an understanding of the organization of these communities and the effectiveness of their functioning based on the same rules.

Keywords: Thomas More, New Harmony, kibbutz, rationality.

Agata Grudzińska

aga.grudzinska@gmail.com

Studia nad Autorytaryzmem i Totalitaryzmem 41, nr 2, 2019

(C) for this edition by CNS 